\title{
Praktik Deskripsi dan Klasifikasi Khazanah Arsip Paku Alam V (1878-1900) di Puro Pakualaman Yogyakarta

\author{
Iskarohma binti Nurhamidyah ${ }^{1}$, Yofa Pradhani Nabillah ${ }^{2}$, Lillyana Mulya ${ }^{3}$ \\ ${ }^{123}$ Sekolah Vokasi, Universitas Gadjah Mada
}

\begin{abstract}
Description and classification are the core of archives management activities. These two stages are often studied in order to understand archives in the context of their creation and to construct ideal retrieval tools. However, the study of arrangement and description of local archives is still limited. For this reason, this paper intends to explain the arrangement and description of Paku Alam $\mathrm{V}$ archives in Puro Pakualaman. This research, which using qualitative descriptive methods, analyzed the main data obtained from participatory observation in the process of organizing the Paku Alam V archive, especially the classification and description stages. The conclusion of this study, namely the classification and description of the Paku Alam V archives, shows that the Pakualaman government has two administrative structures which form the basis of archival grouping. In addition, archival descriptions written in local languages indicate that access to this information is still limited to local researchers or those who understand Javanese source languages, as a language of the majority of Paku Alam V archives. Moreover, knowledge of the classification system and description above can be a guide to read the archives in its history as a formal communication medium for the zelfbestuur government in Yogyakarta.
\end{abstract}

Submitted: 09/06/2020

Received: 09/08/2020

*Correspondence: Iskarohma binti Nurhamidyah

iskarohmabn@gmail.com

KEYWORDS:

classification

description

Archives

Paku Alam V

Puro Pakualaman

KATA KUNCI: klasifikasi deskripsi $\operatorname{arsip}$

Paku Alam V

Puro Pakualaman pengelompokan. Selain itu, deskripsi arsip yang ditulis dengan bahasa lokal menunjukkan bahwa informasi ini masih ditujukan terbatas untuk peneliti lokal atau peneliti yang memahami bahasa sumber Jawa, sebagai pengantar mayoritas arsip Paku Alam V. Lebih daripada itu, pengetahuan tentang sistem klasifikasi dan deskripsi di atas berpotensi menjadi petunjuk untuk membaca arsip dalam riwayatnya sebagai media komunikasi formal pemerintahan zelfbestuur di Yogyakarta.

\section{INTISAR}

statis. Dua tahapan ini sering dikaji untuk memahami arsip dalam konteks penciptaannya dan menyusun sarana temu balik yang ideal. Sayangnya, ini dimaksudkan arsip untuk arsip lokal masih terbatas. Untuk itu, tulisan Alam V di Puro Pakualaman. Penelitian ini, yang menggunakan metode deskriptif kualitatif, menganalisis data utama yang didapatkan dari observasi partisipatif dalam proses penataan arsip Paku Alam V, terutama tahapan klasifikasi dan deskripsi. Kesimpulan dari kajian ini yaitu klasifikasi dan deskripsi arsip Paku Alam V, menunjukkan bahwa pemerintahan
CITE THIS ARTICLE:

Nurhamidyah, I., Nabillah, Y.P., Mulya, L. (2019). Praktik Deskripsi dan Klasifikasi

Khazanah Arsip Paku ALam V (1878-1900) di Pura Pakualaman Yogyakarta. Jurnal Diplomatika, 3(1), 110 - 


\section{PENDAHULUAN}

Artikel ini bertujuan untuk mengenalkan proses klasifikasi dan deskripsi arsip Paku Alam V yang diciptakan sekitar tahun 1878-1900. Pakualaman merupakan sebuah pemerintahan monarki termuda di Yogyakarta dan diperintah oleh pemimpin bergelar Paku Alam. Dalam menjalankan administrasinya di masa lalu, Pakualaman menghasilkan arsip dalam berbagai bentuk, terutama tekstual dan kartografi. Dalam kajian ini, untuk memudahkan penyebutan maka arsip-arsip hasil administrasi pada pemerintahan bumiputera di masa pemerintahan Hindia Belanda disebut dengan istilah arsip lokal. Sementara arsip pemerintahan Hindia Belanda popular dengan istilah arsip kolonial.

Diketahui, di Yogyakarta dan Surakarta (vorstenlanden), terdapat dualisme pemerintahan yang keduanya meninggalkan rekam jejak berupa arsip. Saat ini, unit kearsipan Puro Pakualaman menyimpan semua arsip dari Paku Alam I hingga VIII, namun belum semua arsip tersebut diolah dan dibuatkan jalan masuk. Tahun 2016, total terdapat sekitar 260 boks arsip yang disimpan di Puro Pakualaman. Arsip-arsip itu berasal dari berbagai unit fasilitatif seperti kepegawaian dan tata kelola organisasi serta substantif seperti bidang agraria, pendidikan, adat, agama, dan lain sebagainya (Sholikhah, dkk., 2016). Beberapa yang telah diolah dipisahkan dan dibuatkan jalan masuk berupa senarai arsip.

Sebagai satuan administratif, Pakualaman adalah satu pemerintahan otonom di wilayah Vorstenlanden yang berdiri setelah Pangeran Notokusumo melakukan kontrak politik pada tahun 1813 dengan Raffles sebagai penguasa Inggris di Jawa. Kontrak politik tersebut menyatakan beberapa hal pokok seperti: 1) pengangkatan Bendara Pangeran Harya (BPH) Notokusumo sebagai Pangeran Mardika di bawah Kerajaan Inggris dengan Gelar Pangeran Adipati Paku Alam I; dan 2) pemberian tanah dan tunjangan, tentara kavaleri, hak memungut pajak, dan hak tahta yang turun temurun. Pemberian tanah kepada Pangeran Notokusumo meliputi sebuah kemantren di dalam kota Yogyakarta (sekarang wilayah kecamataan Pakualaman) dan daerah Karang Kemuning (selanjutnya disebut Kabupaten Adikarta). Daerah Karang Kemuning terdiri dari empat distrik yaitu Galur, Tawangardjo, Tawangsoka, dan Tawangkarto (Poerwokusumo, 1985). Sejak tahun 1816, Kadipaten Pakualaman menjadi pemerintahan dengan status zelfbestuurende landschappen Hindia Belanda. Dengan status tersebut, Kadipaten Pakualaman (juga Kasultanan Yogyakarta) tetap memiliki sistem pemerintahan mandiri untuk mengatur wilayah-wilayahnya.

Di Kabupaten Adikarto, ekonomi kolonial digerakkan oleh pabrik gula, di antaranya yaitu pabrik gula Sewu Galur dan pabrik pengolahan indigo Sumbernila. Keberadaan industri gula menjadi penyumbang kekayaan bagi bangsawan Vorstenlanden yang menyewakan tanahnya kepada pengusaha Eropa untuk ditanami tebu atau tanaman industri lainnya. Kehidupan sosial para bangsawan turut dinamis sejak kedatangan orang-orang Eropa. Interaksi inilah yang disinyalir menjadi pemicu sifat konsumtif para bangsawan, hingga membuat mereka akhirnya jatuh miskin karena memiliki banyak hutang (Bahauddin, 2015:18-22).

Kemiskinan menjadi realitas utama yang dihadapi Paku Alam V saat naik tahta, sehingga fokus utama pemerintahannya adalah memperbaiki manajemen finansial keraton Pakualaman (Sudibyo, 2015:122-123). Berbagai usaha penghematan dilakukan untuk menyeimbangkan neraca perekonomian kadipaten. Namun dalam keadaan yang sulit itu, Paku Alam V juga menjadi pionir bangsawan Jawa Tengah yang mengirim putra-putrinya untuk menempuh pendidikan Barat hingga ke Eropa. Tercatat, beberapa keturunan Paku Alam V memiliki kontribusi dalam pemikiran nasionalisme 
seperti Notodirodjo yang aktif dalam organisasi pergerakan Budi Utomo, serta Kusumo Yudo yang berhasil menjadi angota Raad van Indie dan menjadi bupati Ponorogo selama lebih dari satu dekade. Kesadaran Paku Alam V tentang keadaan keraton dan upayanya dalam memanfaatkan kesempatan untuk memajukan ketrampilan putraputrinya melalui pendidikan Barat membuatnya berbeda dengan bangsawan Jawa Tengah lainnya. Keberhasilan Notodirodjo sebagai ahli keuangan keraton cukup berhasil dalam memperbaiki kekuatan finansial Pakualaman. Tidak berlebihan memang jika kajian terhadap Paku Alam V menyebutnya sebagai seorang aristomodernis (Sudibyo, 2015:121-127, 132).

Karakteristik Paku Alam V dalam pola pemerintahannya, yang juga didukung dengan gejolak periode akhir abad 19, membuat rekam jejaknya (terutama arsip) menjadi sumber kajian historis yang kaya informasi. Oleh karenanya, arsip Paku Alam $\mathrm{V}$ masuk ke dalam prioritas arsip yang diolah. Kebijakan reorganisasi dalam bidang keuangan menjadi ciri khas dari tata kelola Paku Alam V. Disebutkan pula bahwa menurut Paku Alam V, kualitas kepemimpinan dapat diukur dari penegakan hukum, delegasi wewenang, dan pembagian kekuasaan (Sudibyo, 2015:128). Pada masa pemerintahannya, intensitas perselisihan administratif yang direkam dalam arsip peradilan meningkat karena perubahan sistem perpajakan yang mempengaruhi relasi sosial pegawai Eropa dan pejabat desa di wilayah Adikarto (Margana, 2007:96). Meskipun relasi sosial dalam area perkebunan tidak lebih baik daripada perkebunan di wilayah lain di Yogyakarta, pemerintahan Paku Alam V masih menempatkan norma adat sebagai penyeimbang dalam perselisihan antara warganya dengan orang Eropa. Pada tahun 1900, kekuasaan Paku Alam V berakhir dan digantikan oleh Paku Alam VI, seorang putra dari Paku Alam V (Poerwokoesoemo, 1985).

Dari aktivitas pemerintahan zelfbestuur yang dinamikanya sedikit disinggung di atas, dihasilkan khazanah arsip yang memuat segala kegiatan dalam struktur pemerintahan Kadipaten Pakualaman. Menurut ilmu kearsipan, struktur pemerintahan yang memuat tugas pokok dan fungsi dalam sistem administrasi merupakan dasar untuk klasifikasi arsip (Duranti, 1989; Perka ANRI No.19 tahun 2012). Dalam artian, praktik pengelompokan arsip Pakualaman mengikuti struktur waktu dan tempat arsip diciptakan. Saat itu, terdapat dua struktur dalam tata pemerintahan Pakualaman, yaitu 1) Kadipaten Pakualaman; dan 2) Kabupaten Adikarto.

Realitas lain yang harus juga dipahami dalam kajian arsip Pakualaman adalah status zelfbestuur. Meskipun disebut dengan pemerintahan mandiri, namun dalam konteks pemerintahan kolonial sistem ini tidak sepenuhnya mandiri. Pemerintahan keraton ini merupakan sebuah sub-pemerintahan kolonial yang dikontrol oleh pusat (Batavia) melalui perantara residen. Perkara-perkara seperti pemilihan putra mahkota maupun kebijakan-kebijakan ekonomi masih harus mendapatkan persetujuan dari residen. Oleh sebab itu, kajian diplomatik terhadap bentuk-bentuk surat juga berkontribusi dalam rekonstruksi arsip Pakualaman.

Sejak masa kemerdekaan hingga K.G.P.A.A. Paku Alam X saat ini, Kadipaten Pakualaman merupakan pemerintahan sosiokultural (entitas keluarga dan budaya). Pura Pakualaman dan berbagai warisan serta potensi kekayaan intelektual yang ada di dalamnya semakin terbuka bagi para pemerhati Kadipaten Pakualaman. Oleh karena itu, pelayanan masyarakat menjadi pilihan kebijakan yang diutamakan. Dengan cara tersebut K.G.P.A.A. Paku Alam IX dan Kadipaten Pakualaman semakin menegakkan keberadaannya sebagai pereksa dan pemangku kebudayaan (Suryodilogo, 2012:44). Entitas keluarga itulah yang membuat khazanah arsip Pakualaman dapat juga disebut sebagai khazanah arsip pribadi (private). Oleh karenanya, Pakulaman tidak memiliki 
kewajiban untuk menyerahkan arsipnya kepada lembaga kearsipan, walaupun sifatnya statis (Rakhmawati, dkk., 2018:32).

Saat ini, arsip Pakualaman terbatas dikaji oleh sejarawan untuk merekonstruksi masa lalu di Yogyakarta, sementara kajian di bidang kearsipan masih belum cukup untuk menjustifikasi bagaimana khazanah arsip dapat menggambarkan sebuah seni pemerintahan. Keahlian dalam mengklasifikasikan dan mendeskripsikan arsip merupakan modal untuk menganalisis arsip dalam satu kesatuan koleksi. Sayangnya keterbatasan ketrampilan bahasa sumber menjadikan khazanah arsip lokal ini jarang untuk dilirik. Oleh sebab itu, artikel ini diharapkan dapat mengisi kekosongan kajian arsip lokal dalam hubungan historical-administrative-legal-archival study.

\section{METODE PENELITIAN}

Metode pengumpulan data yang digunakan antara lain studi pustaka, wawancara, serta observasi parsitipatif. Metode penelitian studi pustaka dilakukan dengan cara menelusuri pustaka yang relevan dengan topik kajian. Tujuannya untuk mendapatkan referensi kajian terdahulu, baik dari konsep maupun pendekatan, sehingga kajian ini dapat menemukan otentisitasnya. Sumber pustaka yang digunakan pada penelitian ini berupa buku, jurnal, kebijakan, laporan akhir studi, dan sumber referensi yang mendukung serta sesuai dengan tema penulisan.

Metode kedua, yaitu wawancara dilakukan dengan cara menjaring informasi atau data melalui interaksi lisan. Dalam pelaksanaannya penulis melakukan wawancara dengan beberapa narasumber mengenai pengorganisasian dan pengolahan arsip Paku Alam yang ada di Puro Pakualaman. Selanjutnya observasi partisipatif yang dilakukan dengan terlibat langsung dalam proses klasifikasi dan deskripsi arsip Paku Alam V selama dua bulan sejak Januari hingga awal Maret 2020. Dari metode ini didapatkan pengetahuan tentang proses klasifikasi dan deskripsi. Selain itu, didapatkan pula dokumentasi beberapa arsip yang turut dicantumkan pada artikel ini.

Selanjutnya, data disajikan secara deskriptif kualitatif yang dilakukan bertahap dengan reduksi data dalam bentuk penyederhanaan, penyajian data dokumentasi, serta kesimpulan dan verifikasi (Lubis, 2018: 44-45). Diharapkan kajian kualitatif ini dapat memberi sumbangan pada penyempurnaan praktik/kegiatan pengolahan arsip di Puro Pakualaman.

\section{HASIL DAN PEMBAHASAN}

Klasifikasi arsip, dalam Undang-Undang No. 43/2009 tentang kearsipan, disebut sebagai salah satu instrument utama bagi penyelenggaraan kegiatan kearsipan. Setelah skema klasifikasi ditentukan, diharapkan penataan arsip menjadi lebih sistematis sehingga memudahkan penemuan kembali arsip. Selama ini, pengelolaan arsip Pakualaman di unit kearsipan Arsip Puro Pakualaman didampingi Dinas Perpustakaan dan Arsip Daerah Provinsi Daerah Istimewa Yogyakarta. Sementara khusus untuk kegiatan restorasi arsip didampingi langsung oleh Arsip Nasional Republik Indonesia.

Kegiatan klasifikasi yang dilaksanakan dalam pengelolaan arsip Paku Alam V memiliki perbedaan dengan pengolahan arsip statis pada umumnya. Hal ini karena arsip ini diciptakan sebelum Indonesia merdeka, sehingga penentuan prinsip asal usul tetap mengacu pada struktur lama. Sebelumnya, menurut keterangan dalam inventaris arsip Paku Alam V, arsip Pakualaman pernah ditata secara sederhana oleh pihak Kadipaten Pakualaman, yaitu dengan menata arsip aktif di dalam amplop sesuai dengan nomor urut surat masuk pada buku agenda. Namun, penyimpanan arsip 
tersebut tidak sistematis karena disimpan di dalam amplop yang ditumpuk acak dan tidak sesuai dengan nomor urut buku agenda. Penataan ini mengakibatkan arsip tidak memberkas sesuai dengan permasalahan. Bahkan dalam satu amplop dapat berisi lima permasalahan yang berbeda-beda.

Dalam pengelolaan arsip statis pada umumnya, tahapannya meliputi 1) akuisisi dan penilaian; 2) klasifikasi dan deskripsi; 3) preservasi; dan 4) akses. Lebih spesifik lagi, kajian ini fokus pada penataan dengan kegiatan pokok klasifikasi dan deskripsi. Dalam praktik penataannya, terdapat tantangan besar yaitu bahasa pengantar arsip. Terdapat beberapa bahasa dan aksara yang digunakan dalam khazanah arsip Paku Alam V, di antaranya bahasa dan aksara Jawa serta bahasa Belanda dengan aksara Latin. Keunikan ini membuat tahapan deskripsi untuk mengetahui subjek arsip harus dilakukan terlebih dahulu sebelum klasifikasi.

\section{Deskripsi Arsip Paku Alam V}

Deskripsi arsip merupakan salah satu dari tahapan pengolahan arsip statis. Menurut Freddric M. Miller dalam Luciana Duranti (1993: 47):

"Archival description is the process of capturing, collating, analyzing, controlling, exchanging, and providing access to information about 1) the origin, context, and provenance of different sets of records, 2) their filing structure, 3) their form and content, 4) their relationship with other records, and 5) the ways in which they can be found and used."

Dalam terjemahan bahasa Indonesia, deskripsi arsip diartikan sebagai proses menangkap, menyusun, menganalisis, mengontrol, menukar, dan menyediakan akses informasi tentang: 1) keaslian, konteks, dan asal atau sumber arsip yang berbeda, 2) struktur pengarsipannya, 3) bentuk dan konten, 4) keterkaitan dengan arsip lainnya, dan 5) cara arsip dapat ditemukan dan digunakan.

Di Indonesia, standar deskripsi arsip statis telah diatur dalam Peraturan Arsip Nasional Republik Indonesia Nomor 14 Tahun 2018 tentang Standar Deskripsi Arsip Statis. Dalam peraturan tersebut, dijelaskan tentang deskripsi berjenjang yang dimulai dari fonds, series, file, hingga item pada arsip tekstual, kartografi, audiovisual, dan lainnya. Dalam implementasinya, arsiparis harus mencatat informasi pada elemen wajib dan tambahan di setiap jenjang/tingkat. Pada elemen wajib, paling tidak informasi seperti: kode unik, judul, kurun waktu, deskripsi fisik, tingkat deskripsi, kontributor penerbit, serta lingkup dan isi harus didapatkan dan dicantumkan. Sementara elemen tambahan meliputi kurun waktu pengolahan dan catatan tim arsiparis yang mengolah arsip tersebut.

Dalam khazanah arsip Pakualaman, jenis arsip paling banyak adalah arsip tekstual berbentuk surat. Format surat yang sering dijumpai sebagaimana pada Gambar 1; Gambar 2; dan Gambar 3. 

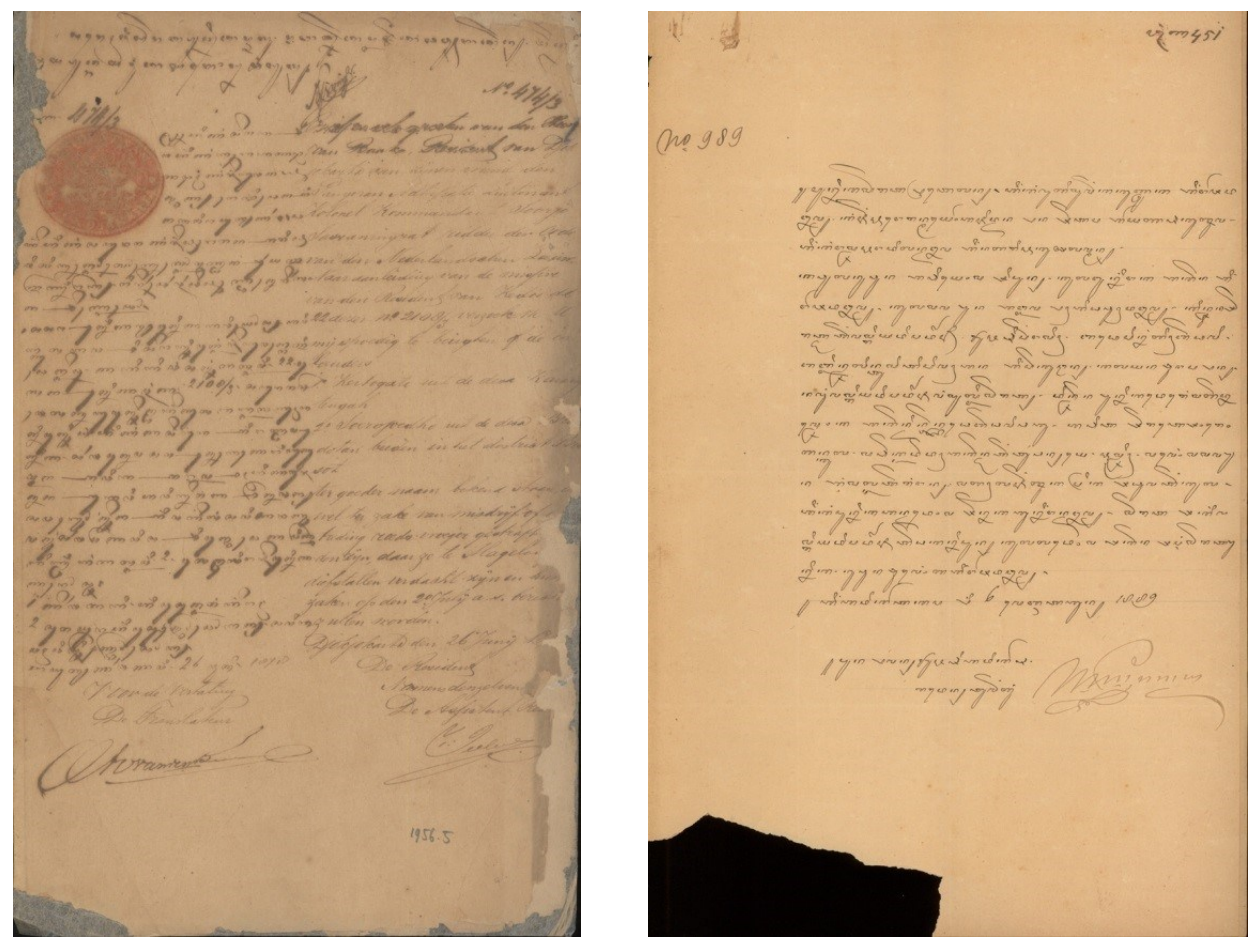

Gambar 1. (kiri) Surat dengan dua bahasa dan aksara yang berbeda (Jawa-Latin), (kanan) Surat dengan bahasa dan aksara Jawa (Terbanyak Dijumpai)

(Daftar Arsip Paku Alam V Tahun 2020 No. Arsip 2 dan 38)

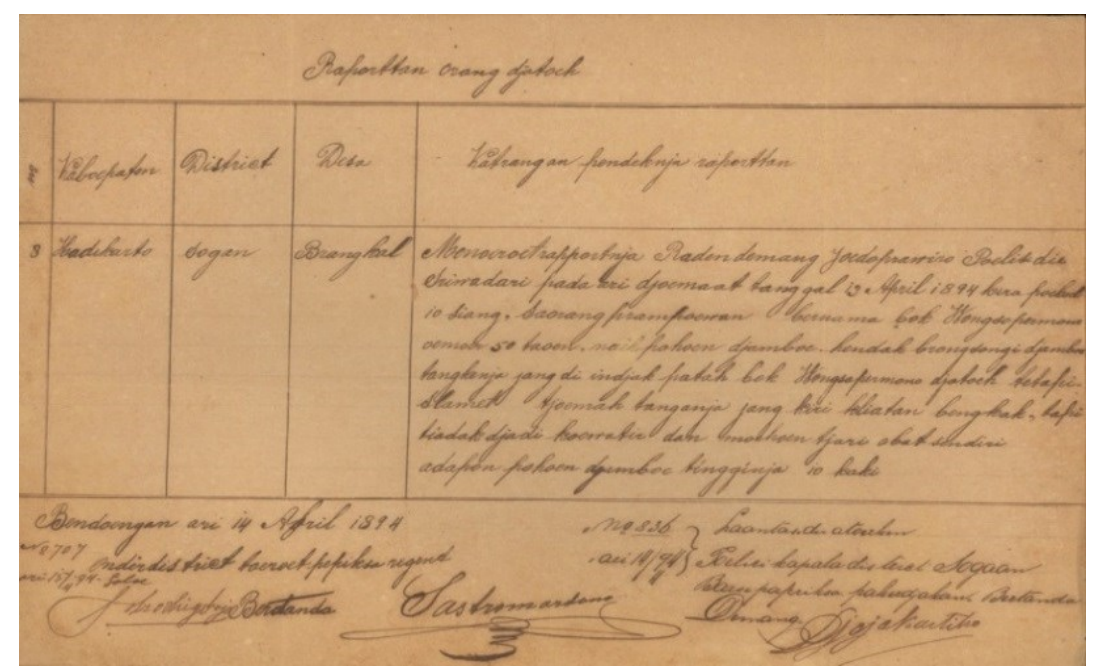

Gambar 3. Surat tentang laporan berbentuk tabel (Daftar Arsip Paku Alam V No. Arsip 81)

Penjelasan setiap tahapan deskripsi arsip Paku Alam V adalah sebagai berikut:

a. Pemilahan arsip periode Paku Alam V dan kondisi arsip

Tahapan ini dilakukan karena arsip Paku Alam I-VIII masih bercampur menjadi satu dalam satu boks arsip. Dengan kata lain, sebelum diolah arsip di Puro Pakualaman tergolong arsip kacau/tidak teratur. Untuk arsip periode Paku Alam V mengacu pada kurun waktu antara Oktober 1878-6 November 1900. Prioritas deskripsi ditujukan pada arsip yang tidak rapuh, sementara arsip yang rapuh (rusak) disisihkan untuk diputuskan agenda restorasi. 


\section{b. $\quad$ Transliterasi arsip}

Tahapan ini termasuk tahapan opsional yang ditentukan kemampuan bahasa arsiparis. Jika arsiparis sudah berpengalaman membaca aksara dan memahami bahasa yang digunakan pada arsip, maka tahapan transliterasi dapat dilewati. Arsip Paku Alam V sebagian besar menggunakan aksara Jawa sehingga jika arsiparis kurang memahami isi arsip, alih tulisan cukup membantu memahami arsip dan meminimalisasi kesalahan informasi dalam deskripsi. Sarana bantu dalam proses ini adalah buku Pepak Basa Jawa. Berikut adalah contoh arsip yang telah di alihaksarakan ke dalam tulisan latin/roman:

Punika serat pratelan ingkang mugi sumengka kunjuk ing ngarsa dalem Kanjeng Pangeran Mayor Ajidan Pan Setap Arya Natakusuma ingkang ngasta Pangadilan Dalem ing Nagari Pakualaman.

Kawula nuwun awiyosipun. Kula nguningakaken ing ngarsa dalem, kula sampun anglampahi dhawuh dalem, kintun serat dhateng Mas Riyadi Padirja Bupati Pengasih. Badhe pinanggih Bedhami bab linta lintu siti pimahan ing Pekuthan kalayan Sungapan namung Mas Riyadi Padirja mangsuli serat. Dinten punika dereng saged namtokaken dinten badhe Bedhami wau. Awit serat sorogan kula saweg kadedahaken dhateng Tuwan Yopresti samongsa sampun angsal katerangan sagah lajeng suka priksa dhumateng kula.

Ingkang punika andadosna kauningan dalem, serat saking Mas Riyadi Padirja tedhakanipun ladosaken sareng serat punika. Nuwun sumonggo ing ngarsa dalem.

Ing Adikarta kapaping 6 Mei taun 1889

Pun Paman Bupati Adikarta

Raden Tumenggung Sasradigdaya

Setelah ditransliterasi, bagian arsip/surat dapat diidentifikasi dengan mudah. Identifikasi bagian-bagian arsip dapat dicermati pada gambar di bawah.

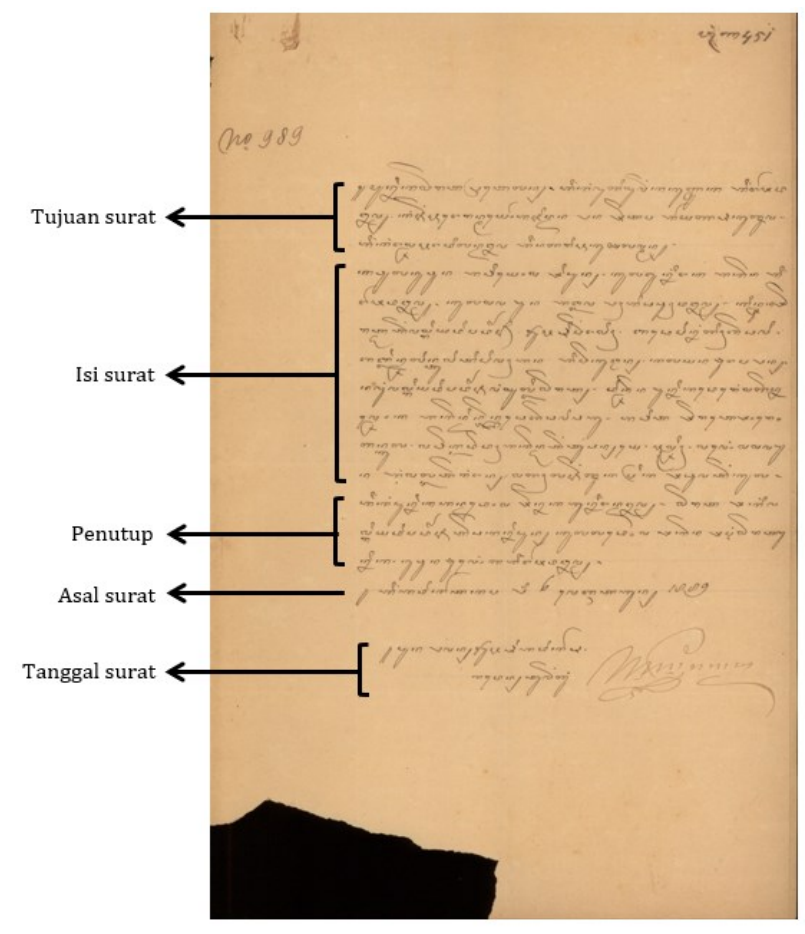

Gambar 3. Arsip yang telah dialihaksarakan dan akan dideskripsi 
Memahami konten dan konteks arsip merupakan hal wajib sebelum menuliskan informasi dalam deskripsi. Sarana bantu dalam bentuk kamus bahasa Jawa maupun kamus online disarankan untuk mencari arti kata yang tidak dikenal misalnya kata bêdhami. Dalam penelitian ini, website utama yang digunakan adalah https://www.sastra.org/leksikon.

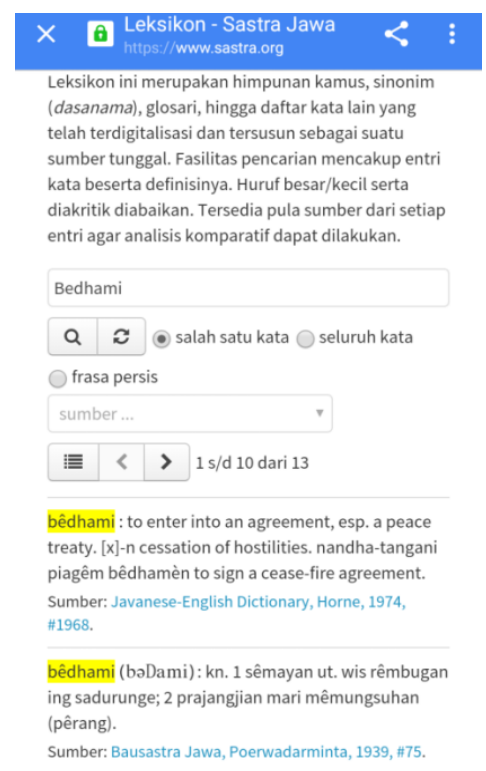

Gambar 4. Pencarian terjemahan kata di sastra.org/leksikon

d. Menulis kartu deskripsi

Informasi deskripsi arsip dituliskan pada form deskripsi yang elemennya telah disediakan Puro Pakualaman. Berikut beberapa informasi yang dimuat dalam form deskripsi.

1. Nomor definitif

Terdiri dari kode arsiparis/petugas yang melakukan deskripsi (dapat berupa inisial nama) dan nomor urut deskripsi arsip. Misalkan nama petugas Yofa disingkat menjadi YF dan diberi nomor urut deskripsi arsip, menjadi YF/01, YF/02, YF/03, dan seterusnya.

2. Kode periode Paku Alam

Pada kartu deskripsi diberi kode periode Paku Alam yaitu Paku Alam disingkat menjadi PA dan diberi angka romawi periode Paku Alam ke berapa, yaitu PA V.

3. Katur

Katur diisi kepada siapa surat tersebut ditujukan. Tujuan surat biasanya terletak pada paragraf pertama surat yang ditandai dengan awalan kata "katur ing" atau "kunjuk ing". Contohnya, surat di atas ditujukan kepada:

“....kunjuk ing Ngarsa Dalem Kanjeng Pangeran Mayor Ajidan Pan Setap Arya Natakusuma ingkang ngasta Pangadilan Dalem ing Nagari Pakulaman.

\section{4. $\quad$ Sangking}

Sangking adalah dari mana asal surat tersebut. Asal surat biasanya diketahui dari bagian paling bawah arsip yaitu pada bagian tanda tangan. Bagian ini memuat pokok yang sulit diidentifikasi yaitu tanda tangan, karena nama 
pengirim menggunakan aksara Jawa yang ditulis sedemikian rupa menjadi tanda tangan.

"Pun Paman Bupati Adikarta Raden Tumenggung Sasradigdaya"

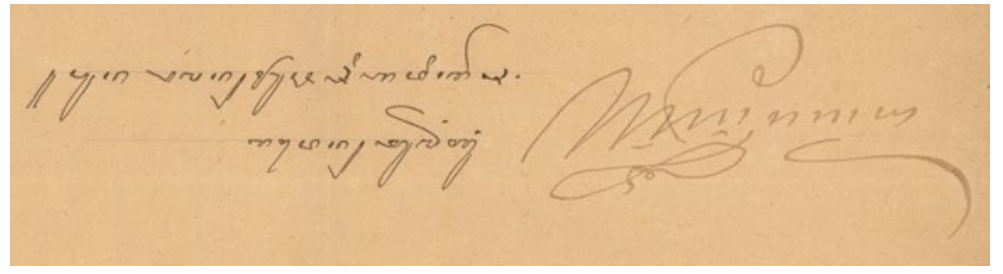

Gambar 5. Asal dan nama pengirim surat

5. $\mathrm{Bab}$

$B a b$ adalah komponen yang memuat isi ringkas/pokok arsip. Isi pokok arsip terletak pada paragraf kedua atau paragraf tengah. Pada tahap ini, diperlukan pemahaman dalam menentukan informasi yang harus dicantumkan supaya dapat meringkas isi arsip dengan efektif.

As the archivist analyzes the collection by asking the questions what activities, who is involved, setting and location, time, consequences of the activities, topics address, and types of materials are included. He or she must also decide whether this information is significant enough to include in a summary description. Part of the archivist's art is determining what ought to be included or excluded (Michael J. Fox dan Peter L. Wilkerson, 1998, 16).

Di bagian sampul surat sudah tertulis bab surat yaitu Bab badhe linton siti badhami boten tamtu dinten rebo ping 8/5/89. Namun bab tersebut belum lengkap, tidak mencakup siapa dan dimana letak siti pimahan yang akan ditukar.

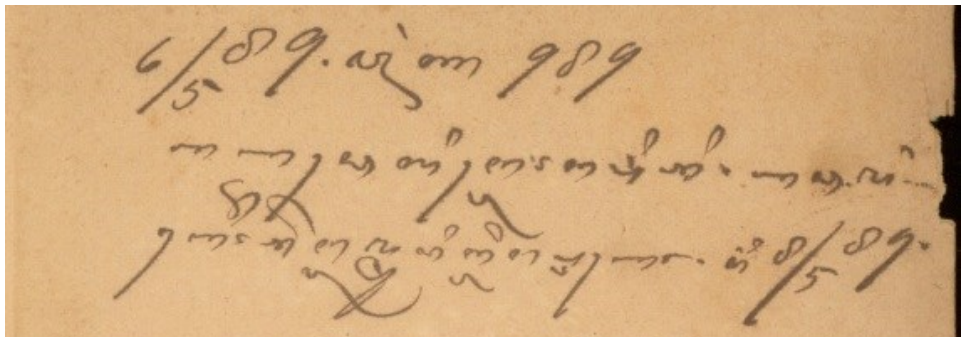

Gambar 6. Tulisan pada sampul surat

Oleh karena itu, ringkasan hanya memuat informasi pokok arsip seperti kegiatan apa, masalah apa, siapa, keterangan waktu dan tempat. Cara peringkasan dapat dicermati pada kata-kata yang diberi garis bawah sebagai berikut:

Kawula nuwun awiyosipun. Kula nguningakaken ing ngarsa dalem, kula sampun anglampahi dhawuh dalem, kintun serat dhateng Mas Riyadi Padirja Bupati Pengasih badhe pinanggih bedhami bab linta lintu siti pimahan ing Pekuthan kalayan Sungapan namung Mas Riyadi Padirja mangsuli serat, dinten punika dereng saged namtokaken dinten badhe bedhami wau. Awit serat sorogan kula saweg kadedahaken dhateng Tuwan Yopresti samongsa sampun angsal katerangan sagah lajeng suka priksa dhumateng kula. 
Setelah itu, maka didapat rangkuman isi arsip sebagai berikut:

Kauningan Mas Riyadi Padirja dereng saged namtokaken dinten punika badhe bedhami bab linta lintu siti pimahan ing Pekuthan kalayan Sungapan.

Dalam isi surat tersebut, dinten punika tidak disebutkan keterangan kapan hari dan tanggalnya. Oleh karena itu bisa dilihat pada sampul surat yang tertulis “...dinten rebo ping 8/5/89". Jadi bab atau isi ringkas arsip tersebut adalah:

Kauningan Mas Riyadi Padirja dereng saged namtokaken dinten Rebo kaping 8 Mei 1889 punika badhe bedhami bab linta lintu siti pimahan ing Pekuthan kalayan Sungapan.

6. Keterangan kondisi arsip

Dalam deskripsi disertakan keterangan keadaan fisik arsip pada bagian bawah kartu deskripsi, misalnya diberi keterangan "Rusak". Menurut wawancara dengan arsiparis Puro Pakualaman, keterangan rusak tidak diberi penjelasan rusak ringan atau berat dikarenakan arsip tersebut akan dicek kembali nantinya oleh DPAD DIY jika akan dilakukan restorasi. Jika arsip yang dideskripsi mengalami sobek seperti ini, maka pada kartu deskripsi diberi keterangan "Rusak".

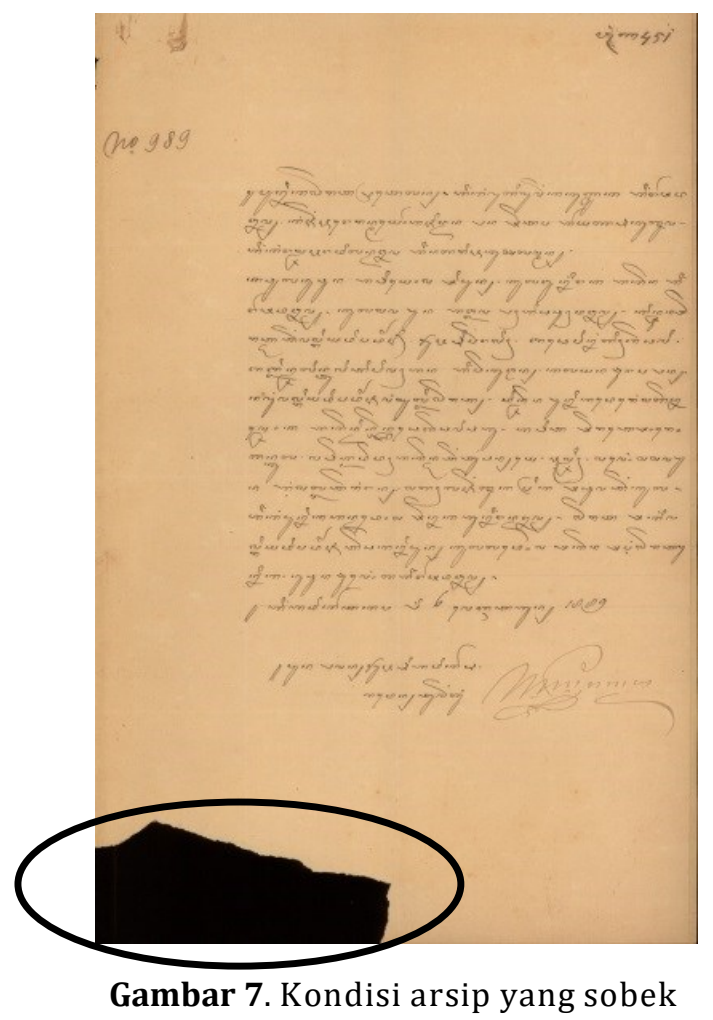

7. Tanggal arsip

Arsip Paku Alam V menggunakan dua jenis penanggalan yaitu penanggalan Jawa dan Masehi. Jika pada arsip tercantum dua jenis penanggalan tersebut maka ditulis keduanya pada kartu deskripsi.

8. Bahasa dan tulisan

Arsip yang menggunakan bahasa dan aksara Jawa pada kartu deskripsi diberi tulisan "Aksara Jawa" serta arsip yang ditulis Latin berbahasa Indonesia dan/atau Belanda pada kartu deksripsi ditulis "Bahasa Indonesia" dan "Bahasa Belanda". 
9. Jumlah fisik arsip

Pada kartu deskripsi, jumlah fisik arsip dapat dinyatakan dalam bendel, lembar dan lainnya. Namun, komponen jumlah fisik arsip dinyatakan dalam jumlah lembar. Contohnya arsip yang sedang dideskripsi di atas berjumlah 4 lembar yaitu 1 lembar sampul dan 1 lembar surat yang menyatu, dan 2 lembar tedhakan (1 lembar bagian belakang kosong).

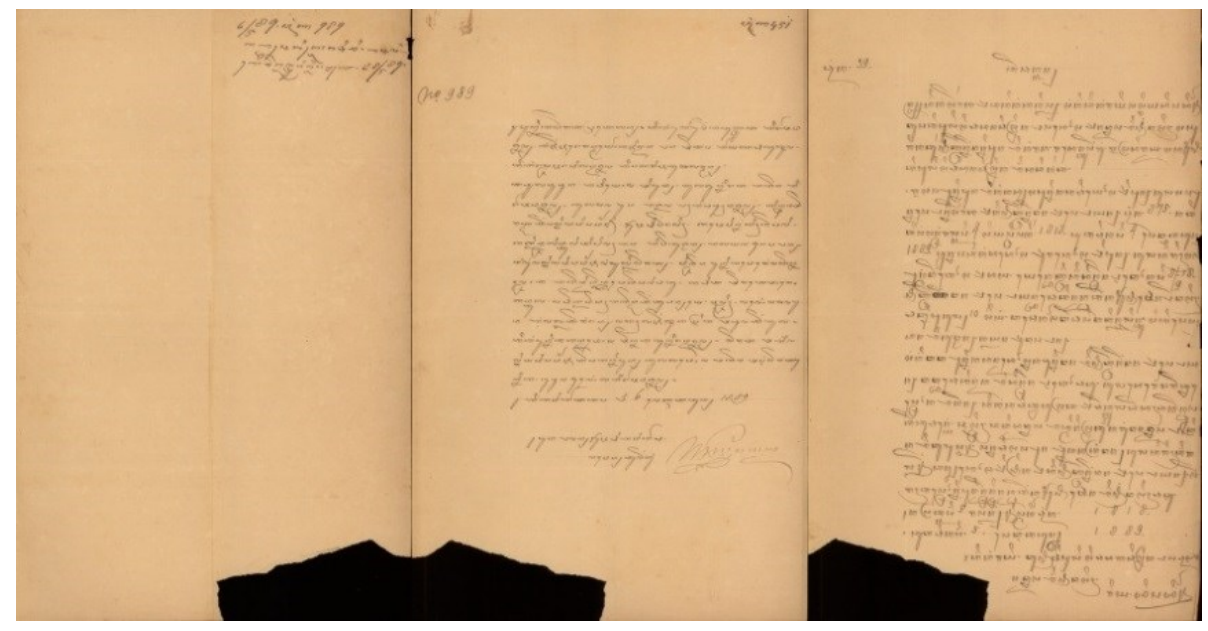

Gambar 8. Sampul surat, surat, dan tedhakan

Berikut adalah hasil deskripsi arsip pada kartu deskripsi:

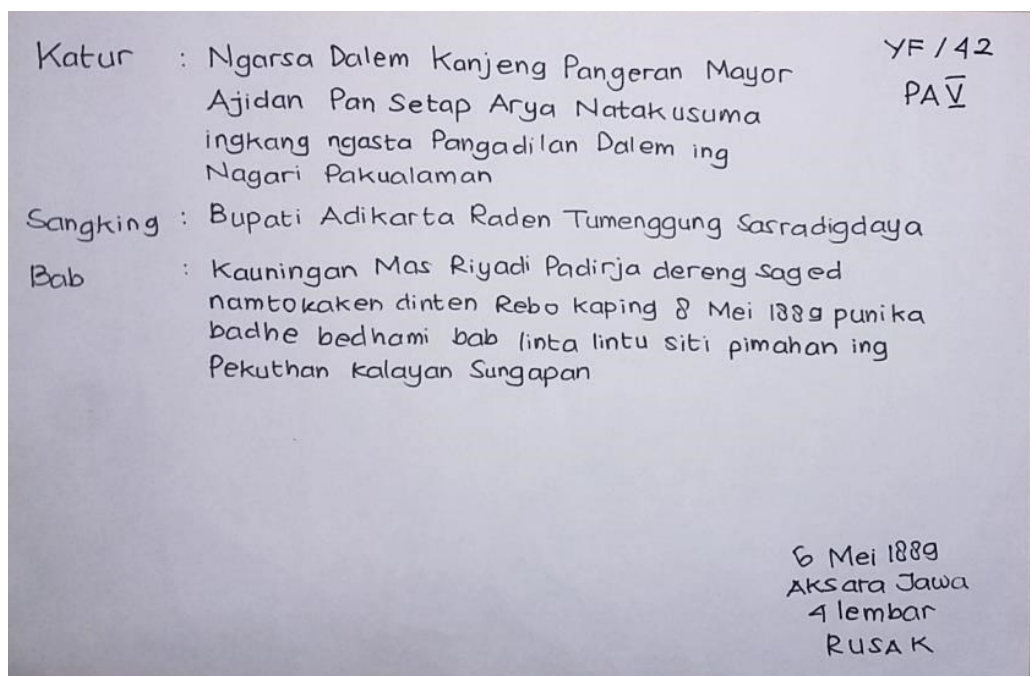

Gambar 9. Kartu deskripsi arsip

Perlu diketahui bahwa, deskripsi ini selanjutnya dituliskan dalam senarai arsip, sehingga kartu deskripsi ini bersifat sementara. Setelah penulisan deskripsi arsip selesai, penanganan fisik arsip dilakukan dengan pembungkusan dengan kertas samson coklat serta penulisan kode periode Paku Alam (PA V) dan nomor definitif di pojok kanan atas untuk memudahkan dalam proses manuver pada tahap penataan.

\section{Klasifikasi Arsip Paku Alam V}

Tahapan klasifikasi dalam pengelolaan arsip Paku Alam V menggunakan struktur administrasi periode yang sama sebagai acuan dalam pengelompokkan arsip. Praktek pengelompokan, sebagaimana dijelaskan pula dalam inventaris arsip Paku Alam V, menggunakan prinsip provenance sebab keadaan arsip tidak memberkas dalam 
penataan terdahulu. Rubrik arsip lantas berpedoman pada fungsi di mana surat ditujukan, seperti: 1) Surat-surat tentang Pranatan; 2) surat kepada Paku Alam; 3) surat kepada Parentah Hageng Kepatihan; 4) surat kepada Parentah Hageng Adikarto; 5) surat kepada Parentah Kadistrikan; 6) surat kepada Pulisi Kadistrikan; dan 7) surat kepada Pengadilan Pakualaman (BPAD, 2018).

Belum diketahui secara pasti hingga tahun berapa struktur seperti ini digunakan. Namun, setelah tahun 1951, diketahui pasti bahwa Kadipaten Pakualaman tidak lagi membawahi Kabupaten Adikarto sebab daerah ini dimasukkan ke wilayah Kabupaten Kulon Progo hingga kini. berikut:

Menurut observasi, tahapan klasifikasi arsip Paku Alam V dijelaskan sebagai

\section{a. Manuver kartu deskripsi}

Dalam tahapan ini, kartu deskripsi digunakan sebagai alat untuk mengetahui asal usul arsip dengan cara mengelompokkannya berdasarkan tujuan surat (katur). Misalnya deskripsi arsip tentang surat masuk dari Residen kepada Parentah Ageng Pakualaman dijadikan satu dengan deskripsi lain yang sama-sama ditujukan kepada Parentah Ageng Pakualaman. Tujuannya yaitu untuk mempermudah arsiparis dalam mengetahui dan menentukan arsip mana yang memiliki tujuan surat yang sama.

b. Penyusunan skema klasifikasi

Pada tahapan ini, dilakukan identifikasi tingkatan arsip (fonds, sub fonds, seri, sub seri, file, dan item) serta pemberian kode khusus untuk memudahkan penataan dan temu balik arsip. Arsip Puro Pakualaman menggunakan dua struktur organisasi yaitu struktur pemerintahan Paku Alam V dan struktur pemerintahan dari Kabupaten Adikarta sebagai pedoman dalam penyusunan skema klasifikasi.

Dari tahapan ini, skema klasifikasi arsip Paku Alam V dibagi menjadi empat tingkatan yaitu:

1. Fonds: Pemerintah Kadipaten Pakualaman masa Paku Alam V tahun $5^{212}$ 1900.

2. Sub Fonds: Parentah Hageng Kadipaten Pakualaman dan Parentah Hageng Adikarta.

3. Series: arsip surat menyurat Paku Alam, arsip surat menyurat Bupati Patih, arsip surat menyurat Bupati Adikarta, dan surat menyurat Pengadilan.

4. Sub Series: Pulisi Kota dan Pulisi Kabupaten Adikarta.

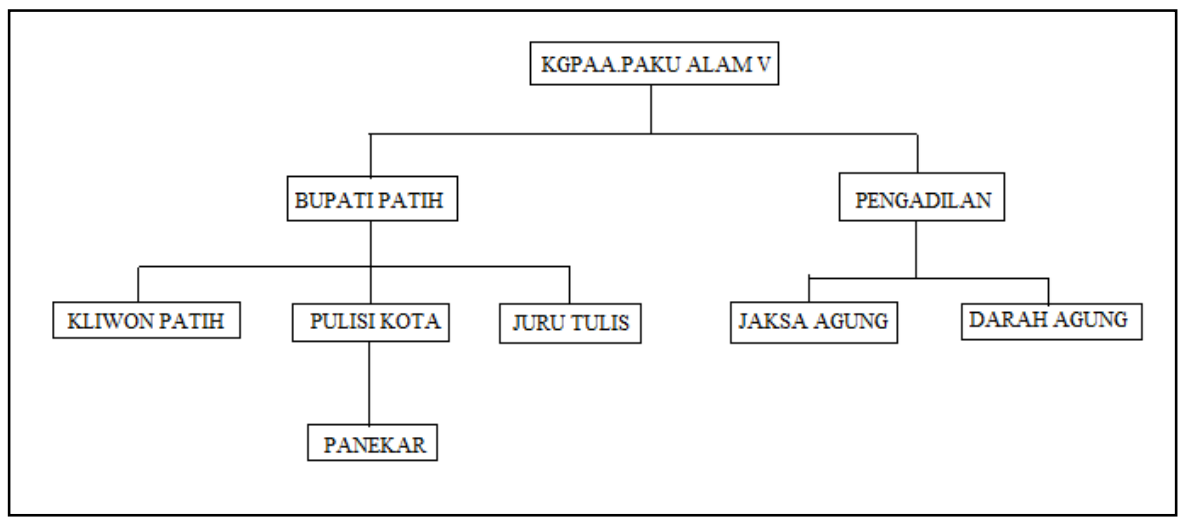

Gambar 10. Struktur administrasi di Kadipaten Pakualaman pada masa Paku Alam V. 


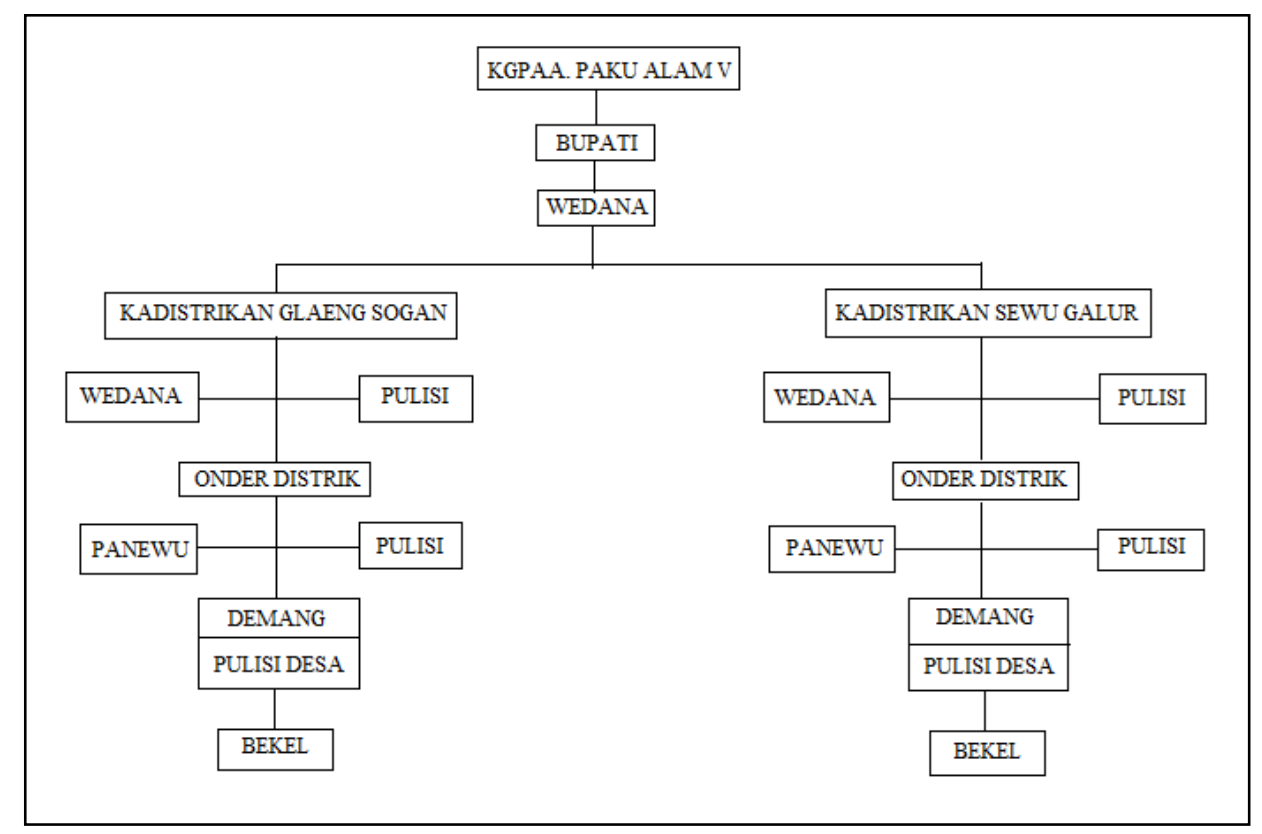

Gambar 11. Struktur administrasi Kabupaten Adikarto pada masa Paku Alam V.

\section{c. Klasifikasi arsip}

Tahapan ini dilakukan dengan cara mengelompokkan fisik arsip sesuai dengan permasalahan. Dalam penerapannya, pengelompokkan terhadap fisik arsip Paku Alam V berdasarkan asal usul dengan tetap menggunakan acuan skema klasifikasi yang telah disusun dan disesuaikan dengan tingkatan surat. Dari tahapan ini dihasilkan kelompok arsip berdasarkan tingkatannya yaitu:

1. Pengelompokkan Seri Paku Alam V (Residen, Parentah Nagari Pakualaman, Parentah Ageng Kapatihan, Bupati Pepatih, Lain-lain dan Pulisi Kitha Pakualaman).

2. Pengelompokkan Seri Parentah Ageng Kabupaten Adikarta (Parentah Ageng Kab. Adikarta, Kadistrikan Galur Gesikan, Kadistrikan Sogan, Kapulisen Adikarta).

\section{d. Input data}

Tahapan terakhir adalah input data berupa kegiatan memasukkan informasi deskripsi arsip Paku Alam V dalam format draft inventaris atau senarai yang telah sesuai dengan skema klasifikasi. Hal ini dilakukan untuk memudahkan dalam penataan fisik arsip kedalam boks serta memudahkan dalam pembuatan inventaris atau senarai.

\section{KESIMPULAN}

Berdasarkan data tentang klasifikasi dan deskripsi arsip Paku Alam V, secara praktis didapatkan penjelasan bahwa deskripsi arsip pada tingkat item lebih efektif dilakukan sebelum klasifikasi. Praktik ini berbeda dengan tahapan pengelolaan arsip statis untuk arsip kontemporer yang meletakkan tahapan klasifikasi di depan deskripsi arsip. Keunikan yang terlihat dalam deskripsi arsip, yaitu unsur-unsur yang tetap memakai istilah Jawa seperti sangking dan katur menjadi titik negosiasi antara standar kearsipan dan pengetahuan lokal. Dalam hal ini, apresiasi layak diberikan kepada pihak Dinas Perpustakaan dan Arsip Daerah selaku lembaga kearsipan yang mendampingi 
pengelolaan arsip yang mempertahankan karakteristik lokal arsip. Namun, deskripsi dalam bahasa Jawa ini akan menjadi faktor penghambat akses arsip secara lebih luas. Sementara dalam tahapan klasifikasi, dua struktur yang dijadikan acuan membagi pengelompokan arsip menjadi dua seri, masing-masing dengan subjek-subjeknya yang khas. Terlihat pula subjek pada struktur Kabupaten Adikarto lebih rumit daripada Kadipaten Pakualaman. Hal ini dapat menunjukkan tingginya aktivitas administratif karena ekonomi terpusat Adikarto.

Bagaimanapun juga, di samping perkara praktis, perkara yang membutuhkan kajian lebih dalam adalah sisi epistimologis penataan arsip yang berkontribusi dalam analisis arsip secara holistik. Dalam hal ini, koleksi arsip Paku Alam V harus dilihat dari konteks penciptaan, sehingga dapat menempatkan arsip Paku Alam V sebagai bagian rekam jejak keadaan akhir abad 19.

Jika kajian kritis tentang arsip selalu diawali dengan bagaimana klasifikasi ditetapkan dan diimplementasikan, maka dalam hal ini struktur harus dikaji lebih dahulu. Dalam kajian selanjutnya, menyertakan pertanyaan seperti sejak kapan fungsi polisi masuk ke dalam struktur Kadipaten Pakualaman dan Kabupaten Adikarto dapat memberikan gambaran sejauh mana pemerintahan zelbestuur dituntut untuk berperan dalam penertiban masyarakat, terutama dalam lingkup kepentingan kapitalisme Eropa.

Selain unsur struktur, tahapan deskripsi juga memberikan kontribusi dalam analisis kekuatan penulisan arsip. Misalnya, pemilihan diksi merupakan representasi keberpihakan juru tulis dalam perselisihan masyarakat lokal dan kulit putih. Melalui pembacaan arsip, juru tulis yang tentu saja seorang Jawa, memiliki kemerdekaan untuk menuliskan secara rinci suatu permasalahan dengan subjektivitasnya. Pada akhirnya, jika keahlian penelaahan arsip seperti ini dikuasai arsiparis, kekayaan arsip Pakualaman, yang tidak saja terbatas pada Paku Alam V, dapat menunjukkan apa yang oleh Eric Ketelaar sebut dengan "tacit naratives of power and knowledge".

\section{Saran:}

Saat ini, deskripsi masih menjadi acuan dalam sarana temu balik khazanah arsip. Baik manual maupun otomatis, keterbatasan deskripsi dalam bahasa Jawa dapat menghambat pemanfaatan arsip. Oleh sebab itu, penerjemahan deskripsi ke dalam bahasa Indonesia dan bahasa Inggris krusial untuk mengantisipasi jika database dimaksudkan untuk perluasan akses secara online. Jika langkah digitalisasi khazanah arsip diambil, pendampingan dari tim ahli juga harus dipertimbangkan, terutama untuk mendudukkan arsip lokal setara dengan arsip kolonial dari periode yang sama. Praktik ini dirasa perlu sejak penggunaan bahasa menjadi kontestasi kuasa dalam sarana temu balik arsip (Jeurgens \& Karabinos, 2020: 13-15). 


\section{DAFTAR PUSTAKA}

\section{Peraturan:}

Peraturan Kepala Arsip Nasional Republik Indonesia Nomor 19 tahun 2012 tentang Pedoman Penyusunan Klasifikasi.

Peraturan Arsip Nasional Republik Indonesia Nomor 14 Tahun 2018 tentang Standar Deskripsi Arsip Statis.

Peraturan Daerah Provinsi Daerah Istimewa Yogyakarta Nomor 5 Tahun 2018 tentang Pelaksanaan Kearsipan.

\section{Inventaris:}

BPAD DIY-PA. (2018). Inventaris Arsip Kadipaten Pakualaman: PA V. Yogyakarta: Kadipaten Pakualaman.

\section{Buku dan artikel:}

Suryodilogo, Atika, dkk. (2012). Warnasari Sistem Budaya Kadipaten Pakualaman Yogyakarta. Jakarta: Trah Pakualaman Hudayana.

Bahauddin. (2015). "Westernisasi dan Gaya Hidup Bangsawan di Kadipaten Pakualaman pada masa Paku Alam V" dalam Jurnal Patrawidya Vol. 71. Yogyakarta: Balai Pelestarian Nilai Budaya Daerah Istimewa Yogyakarta.

Duranti, Luciana. (1989). “Diplomatics: New Uses for an Old Science” in Archivaria 84. (1993). "Origin and Development of the Concept of Archival Description” in Archivaria 91: Spring 7559.

Sholikhah, Faizatush, dkk. (2016). “Arsip Privat: Inventarisasi Khazanah Arsip Pura Pakualaman" dalam Prosiding Seminar Nasional Teknologi Terapan SV UGM 2016. Yogyakarta: Sekolah Vokasi, Universitas Gadjah Mada.

Fox, Michael J., Wilkerson, Peter L. (1998). Archival Organization and Description. Getty Information Institute.

Jeurgens, C., Karbinos, M. "Paradoxes of Curating Colonial Memory" in Archival Sciene 20, 199-220 (2020). https://doi.org/10.1007/s10502-020-09334-Z

Ketelaar, Eric. (2001). "Tacit Narratives: The Meaning of Archives in Archival Science 7: 131-141. Netherlands: Kluwer Academic Publishers.

Rakhmawati, Rina, dkk. (2018). “Gagasan Optimalisasi Kerja Sama Pelestarian Arsip Puro Pakualaman" dalam Jurnal Gama Societa Vol. 7, No. 7. Yoyakarta: Sekolah Vokasi, Universitas Gadjah Mada.

Soedarisman, Poerwokoesoemo (1985). Kadipaten Pakualaman. Yogyakarta: Gadjah 
Mada University Press.

Margana. Sri. (2007). "Hibridity, Colonial Capitalism and Indigenous Resistance: The Case of the Paku Alam in Central Java" in Ulbe Bosma, Juan A. Giusti-Cordero, G.R. Knight (eds.). Sugarlandia Revisited: Sugar and Colonialism in Asia and the Americas, 1800-1940. New York: Berghahn Books.

Sudibyo. (2015). "Paku Alam V: Sang Aristo-Modernis dari Timur" dalam Jurnal Paramita Vol. 25 No.1. Semarang: Jurusan Sejarah, Universitas Negeri Semarang. 